\section{Locating Pawai in the Social Hierarchy of the Khasa: a Preliminary Note on Jumli Caste Structure}

Youba Raj Luintel ${ }^{1}$

\section{Abstract}

Until very recently, Jumla's Pawai, or the Matawali Chhetri, have remained one of the very least understood caste groups in Nepal. In many sense Pawai can be considered as an unusual caste group and possess some unique yet paradoxical socio-cultural traits and claims. Overall, they represent Chhetri sub-caste, but in the Jumli caste hierarchy they are placed lower than Chhetri. They do not wear sacred thread called "janai," do mostly worship masto, and in Bota village, some of them even offer liquor to their Hindu diety. This article attempts to explain the distinctive characteristics of Pawai in light of the Jumli caste hierarchy, and differs from some of the simplistic explanations of human ecological approach to argue that Pawai are simply the by-product of their cultural interface with the local ecology, or the reductionist arguments of identity politics that it is the ethnicity and not the class that differentiates society and forms different identity of the culturally marginalised one. This article first sheds lights on the social construction of Pawai as the kamsel caste group, takes into account the uniqueness of paddy cultivation in Jumla and its caste implications in the local political economy, and then compares and contracts the Pawai vis-a-vis the Jyulel to make an argument that the uniqueness of Pawai can only be meaningfully understood by placing them in their dynamic relationship with Jyulel. This relationship essentially entails a relationship of privilege and deprivation in terms of access to and ownership of jyula (as

${ }^{1}$ Dr Luintel is Associate Professor in Sociology at Tribhuvan University Central department of Sociology and Anthropology. productive low lands). By implication, it is differential access to assets and resources that brings diversity and inequality in society and not the vice-versa.

Keywords: Pawai and Jyulel, caste hierarchy, deprivation and identity.

\section{Introduction}

Until relatively recently Nepalese social scientists, notably the anthropologists and ethnographers overlooked the very existence of the Khasa: the culturally predominant caste group inhabiting Karnali region of Nepal. ${ }^{2}$ It is therefore not surprising that they are still unaware of the Pawai, a small segment of Khasa population. Dor B. Bista, one of the eminent native ethnographers, admits that he was completely unaware about the unique caste group of Khasa in as late as sixth edition of his book (Bista, 1996):

Most anthropologists who have done their studies in Nepal in the past have missed the Khas[a] people altogether...This book "People of Nepal" went through five prints before this one without separate chapter describing the Khas[a] ... It was never before considered necessary to go into an in-depth study and prepare a separate chapter about the Khas[a] people as they were thought to have been included into the chapter, Bahun, Chhetri, Thakuri etc. of the hills.

I have to admit that I was unaware of this until a few years ago (Bista, 1996:74). Given this context of scanty attention on the Pawai, it is therefore obvious that very scanty, passing by and insufficient information is available up on which we cannot rely.

\footnotetext{
${ }^{2}$ Data and observation for the present paper have been derived from a fieldwork in Jumla between March to August 1991 under a research project "Development strategies for the remote areas of Nepal" implemented by the Centre for Nepal and Asian Studies (CNAS), Tribhuvan University and funded by IDRC-Canada. The data was updated and substantiated in June 2013 during my revisit of Jumla for a research in inter-caste relations supported by University Grants Commission.
} 
Perhaps it was Prayag R. Sharma who wrote for the first time a fullfledged paper on matwali Chhetri (Shama, 1971). Luintel (1993) prepared a brief ethnographic note on them as an entry for the proposed Cultural Encyclopaedia of Nepal. ${ }^{3}$ Despite his years of research in the Karnali region, Barry Bishop could mention only passing by notes on matwali Chhetri (Bishop 1990). In a research report, Manandhar et al. (1993) made some elaboration on the Pawai mode of livelihood, part of this paper draws on this report.

In this paper, I attempt to present the socio-cultural milieu of Pawai and consider their lower social position within the predominant Khasa caste structure in Jumla as a manifestation of their lack of access to and command over production of paddy as the valued cereal crop. The central theme of my argument is that the present sociocultural marginalisation of the Pawai is very much related to their ethnographic past of being unable to adapt to the unique cropping practice of marsi variety of paddy, which in fact, is an innovative and ritualised system of wet variety of paddy cultivation in the highest elevation of the world (Bishop, 1990). I would demonstrate that their inability to adapt themselves in the localised system of marsi variety of paddy derives not only from their specific spatial location on the ridges of Jumli hillocks (as opposed to the low beds of Tila and Sinja rivers), as the orthodox arguments claim, it also derives from their social exclusion as the liquor drinking sub-group in their juxtaposition to the so-called chokha Thakuris.

\section{The social construction of Pawai as the kamsel caste group}

Jumla was once a powerful Khasa Kingdom of West Nepal. During the medieval period of political history, Jumla evolved as the centre of socio-cultural, economic and political milieu. Its political domain was extended as far as Dullu in the South and Gunge, Purang of Tibet in

\footnotetext{
${ }^{3}$ The Cultural Encyclopaedia of Nepal was, then, a project under the support of Japan's Toyota Foundation. The project had accomplished preliminary work on various entries already during the mid-1990s, but for some reasons, the encyclopaedia was never published.
}

the North. ${ }^{4}$ Jumla enjoyed an extent of administrative influence even during the Panchayat regime (1961-1990) when it was designated as the zonal headquarters of Karnali. However, in the current political and administrative landscape of Nepal, Jumla enjoys no such privilege. Despite the fact that Jumla has loosened its economic, political and administrative prominence over the years, it is still the central point in the larger canvass of history and culture of the Karnali region. The dichotomised livelihoods of the Pawai and the Jyulel form a part of it.

According to the Nepal Human Development Report 1998, the human development indicators of Jumla were very worse during the mid-1990s. In terms of life expectancy, educational attainment and income indices, the district of Jumla was placed at the $69^{\text {th }}$ rank of the 75 districts (NESAC 1998). ${ }^{5}$ The district of Jumla has been divided into 30 Village Development Committees (VDCs) for administrative purposes. Nevertheless, people find it more meaningful to divide the whole district in four daras: the Sinja dara, the Chudhabisa dara, the Panch-saya dara and the Asi dara. ${ }^{6}$ The total population of the district

${ }^{4}$ According to Giuseppe Tucci, "... about the eleventh century, two Aryan-speaking tribes (from Nepal) broke into Western Tibet. The one took control of Purang and the other Guge" (Tucci 1962, 60-61). In the early twelfth century, Nagaraja, a descendant of the ruling family of Guge moved his capital to Sinja and established the Khasa Kingdom (Bishop 1990). This is how legends describe the establishment of Khasa Kingdom. Harka Gurung cites another legend that describes how the once powerful Khasa Kingdom started to disintegrate. Accordingly one of the Malla rulers insisted one of the Lamas, called Chhichhim Lama from Mugu, to demonstrate his magical powers at the royal palace. Instead of demonstrating magic, the Lama created a heavy earthquake that greatly damaged the buildings of the capital (Gurung 1980, 49). As indicated in this legend, this was the beginning of the demolishment of the Khasa Kingdom.

${ }^{5}$ The latter Nepal Human Development Reports do not disaggregate HDI at district level (see UNDP 2006 and 2009, for example). The HDI for the Mid-Western Nepal region including Jumla was 0.402 in 2001 and there is slight improvement in 2006 with regional HDI being 0.452 . This improvement is not specific to Mid-Western Nepal, but resonates overall improvement in national HDI (from 0.471 in 2001 to 0.509 in 2006)(see UNDP 2009: Table 2.1).

${ }^{6}$ The dara was a native classification system based on geographic specificity and watershed differences. The dara-division was in vogue as late as the local feudal and the village headmen were in charge of collecting the land revenue. The daras are still 
in 1991 census was close to 67 thousand. The Brahmin, the Chhetri, the Thakuri and the Sanyasi were the major chokha caste groups in Jumla, followed by iron-smiths, tailors and cobblers, collectively known as the kamsel caste. Seldom mentioned are the Pawai (the matwali Chhetris) ${ }^{7}$ whose caste position falls in-between the so-called chokha and kamsel division. The actual size of population of the Pawai is hard to identify, as the Central Bureau of Statistics, the national census-taking wing of the government, does not recognise them as a separate population category.

The Pawai are one of the typical caste groups in West Nepal. Within the conventional hierarchy of Hinduism, they are provided a special designation of matwali Chhetri: a unique blend of the socalled upper and lower castes. The adjective "matwali" to the caste group of Chhetri is itself contradictory. This reveals a unique position of the Pawai indicating their ambivalent caste belonging to high caste status of Chhetri yet embracing their "impure" practices of predominantly matwali (literally, the liquor drinking) groups.

The Pawai do not wear the sacred thread, called janai, a customary practice for the dominant Chhetri caste (Sharma 1971). Liquor and chicken are a part of their accepted dietary, which is but a strict taboo for other Chhetri (Sharma ibid). It is said that matwali Chhetri are unaware of having a gotra system for their caste group. ${ }^{8}$ It

meaningful to the local people to mean various geographical contexts, the modern bureaucracy, however, does not consider the importance of dara.

7 The term "Pawai" is not exactly a synonym for the phrase "matwali Chhetri." Etymologically a Pawai is the one "who inhabits in the high elevations, called pakho." Socially it gives a satirical connotation to mean the ones who do not have jyula, irrigated lowland in the basin. As such, they do not have wet crop cultivation as opposed to the Jyulel who own and Jyule who own and cus such, they Wensumption of chicken and alcohol. In the caste hierarchy they are just beneath the Chhetri. In the social structure of Jumla as a whole, the Pawai, majority of whom are matwali Chhetri, are just one end of social dichotomy, of which the Jyulel are the other. To understand the Pawai we also have to understand their Jyulel counterparts. For simplicity purposes the term Pawai and the phrase matwali Chhetri have been used interchangeably in this paper.

${ }^{8}$ The gotra is an exogamous social unit of an assumed common ancestry and a vital consideration for consanguineal and affinal relations among the so-called "upper is also observed that matwali Chhetri do not invite any Brahmin priest in their rites de passage rituals and festive occasions which is a normal practice to other Chhetri. Beside, and I assert this is more important, since the Pawai inhabit in high elevations of slopes; they do not have any jyula, irrigated land. As a consequence, there are many outcomes characteristic to the Pawai.

The Pawai have to depend on dry crop cultivation. In comparison to the Jyulel, the Pawai are relatively poorer mainly because they have no paddy to harvest. (In Jumla, paddy is an export crop and therefore a source of cash income (Shrestha 1993). Due to their higher elevations settlement the Pawai are devoid of induced services of any kind. All services and service centres, for example, are biased towards the Jyulel. They are concentrated on easy access areas of river basin, such as district headquarters itself. Because of their marginalisation, the Pawai are under-represented even in local political units, such as in 30 Village Development Committees and in the District Development Committee in Jumla. The last but not least is the social stigma associated on being a Pawai vis-à-vis the Jyulel.

Due to the exclusive concentration of the Pawai in high (to intermediate) elevations (because the lower elevation with fertile flat lands along the Tila and Sinja river basins are preoccupied by their Jyuleli counterparts, the whole Jumla district can be roughly divided into the Pawai and Jyulel areas. Table 1 demonstrates the Pawai and Jyulel VDCs of Jumla district. It is clear to see that of the 30 VDCs in Jumla, nine are exclusively Pawai, followed by four predominantly Pawai. Other 17 VDCs have missed characteristics. For example, in Kanakasundari VDC, only Kotgaon and Hatsinja villages represent Jyulel area, as they lie on river bed. Likewise, except Pigi and Narakot villages in Narakot VDC, Lihi-Dhital, Gora, Ruga and Thakuri villages in Sanigaon VDC, and Dungri, Tapla and Tamti villages in Tamti VDC share Jyulel characteristics. Otherwise, all these VDCs belong to the Pawai category (Manandhar et al., 1993).

The matwali Chhetri, according to Bista (1996), is a group of 
original Khasa population who did not undergo the process of the conversion of the Khasa into the Kshatriya order. "The presence of a large number of matwali Chhetri, who do not wear the sacred thread, indicates that the process (of caste conversion) was less than complete" (Bista, 1996: 3). Bishop claims that the matwali Chhetri as a caste group represents the "vivid pre-Hindu tribal Khasa vestiges of any Pahari group..." (Bishop, 1990: xx).

Table 1: Division of VDCs in Jumla by Pawai and Jyulel livelihoods

\begin{tabular}{ll}
\hline Completely Pawai VDCs $(N=8)$ & Completely Jyulel \\
& VDCs $(\mathrm{N}=13)$ \\
Bumramadi & Chandan Nath \\
Chhumchour * & Depalgaon \\
Ghode-Mahadev & Dhapa \\
Gothi chour * & Garjyangkot \\
Malikabota & Haku \\
Malikathanta & Kalika-khetu \\
Patmara * & Kartikswami \\
Tamti & Lamra \\
& Mahabai \\
& Mahatgaon \\
& Pandav-gupha \\
& Talium \\
Predominantly Pawai $V D C s ~(N=5)$ & Tatopani \\
& Predominantly Jyulel \\
Dilli chour * & VDCs (N=4) \\
Kanakasundari & Badaki \\
Narakot & Birat \\
Patrasi * & Kundari \\
Sanigaon & Raralihi \\
\hline Source: Field study, 1990 and 2013. & \\
Note: VDCs with aestrick mark represent &
\end{tabular}

Less affected by the process of Brahminisation, the matwali Chhetri continued in their impure practices of consuming alcohol and chicken, and therefore remained, in the eyes of the Brahmans, unfit to wear the janai of the twice born. Yet on the basis of the universal Khas claim that their progenitors were warriors, these matwali Khas cultivators and the pastoralist were recognised by the Brahmans as the fallen Kshatriya. They were, therefore, Chhetri and clean, albeit less pure and as such belonged to the matwali Chhetri jat (Bishop, 1990: 91). Both Bista (1996) and (Bishop, 1990) are common in their points that:

- the matwali Chhetri (therefore, the Pawai too?) are the descendants of the original Khasa population,

- the "incomplete" process of "caste conversion" (also called "Brahminisation") gave rise to the designation of matwali Chhetri caste (a token of derogation for following "impure" practices such as consuming chicken).

I agree to both of them up to a point but I do not see any process of "caste conversion" or so called "Brahminisation". First, there was a little scope for such a process in that Khasa-dominant and Khasa-majority area of Khasan. Second, when we accept that once there was a powerful Khasa empire in Khasan, it is ironic why do we not accept sufficient level of their socio-cultural advancement and continue to argue that they were in a state of "vivid pre-Hindu tribal"? (It is fairly simple to guess that Khasa population in general must have achieved an extent of advancement to become able to create, drive and sustain the political domain of that kind.) Third, because of their high elevation settlement the matwali Chhetri (and also the Pawai) were not in a vantage point in producing paddy. Therefore, it was not their "impure" practices responsible for their socio-cultural deprivation but a crop (say, paddy) which determined their occupation, economic affluence and resultant socio-cultural position. The mutual adjustment of a group in any social hierarchy (such as the caste system) is primarily determined by the relative affluence of the group in question (Ghurye 1961, Srimivas 1961). The basic questions are what occupation do they follow? What do they produce and what 
they do not? Which commodity (crop) is staple for them and which is not?

Obviously, they were the Jyulel (and not other than the Khasa!) who took, by virtue of their settlement at basin area, maximum social and economic benefits by adopting an innovative system of paddy cultivation. It helped boost their social economy so fast that the Pawai lagged far behind. As a manifestation of this gap, dichotomised social stratum, such as the Pawai vs. the Jyulel, the matwali Chhetri vs. the Chhetri/Thakuri, appeared in the Khasa society itself. In the sections that follow it I would present the history of introduction of paddy in Jumla to portray its linkage with the Pawai-Jyulel contrast of livelihood.

\section{The uniqueness of paddy cultivation in Jumla and its caste implications}

The climate of Jumla is not favourable for paddy and not uniform throughout the district. Variations in precipitation have been wider between latitude as well as altitude. The east-west flowing Tila River, for example, lies in rain shadows caused by adjacent high peaks to the south such as the Api-Sapal Himal and the ChyakhureMabu peak (lekh). The climate of the district can be described as high altitude; dry sunny yet cooler temperature; variable rainfall in summer and mild to heavy snowfall in the winter ${ }^{9}$ In response to the climate like this, the Jumli Khasa have innovated a farming system of different kind in which unlike in other parts of Nepal, they have been successful for "forced germination of paddy seeds" a phrase used by Shrestha $(1996,48)$.

The Jyulel are of the opinion that no paddy other than marsi, a special species of paddy suitable in high altitude and alpine climate,

\footnotetext{
${ }^{9}$ The average rainfall of the district is $1225 \mathrm{~mm}$, of which 78 percent occurs in summer. The warmest and coldest months are July $\left(16^{0} \mathrm{c}\right)$ and January $\left(\mathrm{o}^{\circ} \mathrm{c}\right)$, respectively (Shrestha 1993). The Khalanga bazaar of Chhinasim exists at the lowest altitude of $2344 \mathrm{~m}$, Hatsinja village in the north-west at $2600 \mathrm{~m}$. There are high altitude meadows called patan at an altitude of 6627 m. (see Map No. 63, HMG/N, n.d.)
}

can be grown in Jumla. It is also important to note that of the total 24,060 hectare of arable land in Jumla, only 5. 6 percent is suitable for paddy cultivation. ${ }^{10}$ The farming system is quite traditional. Until 1991, the Jyulel used to apply with wood-tipped hoe to plough their land. Very few farmers had tasted the iron-tipped hoe by then. These are the types of constraints under which the Jyulel to farm their land and harvest fairly small amount of paddy. In the year 1993, for example, the Jumli people grew a total of 2880 metric tonne of paddy. If we assume that 67 thousand population of Jumla in 1991 was constant for the year 1993 also, we can safely conclude that one individual Jumli had a share of $43 \mathrm{~kg}$ of paddy for the whole year to come. $^{11}$

The marsi grown in Jumla is considered as one of the Kashmiri varieties of paddy. According to a local legend, a Kashmiri sage Chandan Nath on his way to Mansarovara arrived at Jumla during thirteenth or fourteenth century. During the time, as is claimed, the Jumla valley was a lake. Sage Chandan Nath staged at Siddha Cave, above the present day Bohora gaon, for a hard austerity. Upon his interest, Lachhal Kirti, a famous wrestler of the time and one of the disciples of the sage, cut the hillock near Khala chour, a place between the villages of Micha and Sridhuska, to let the water flow. By the time Chandan Nath was to come back from the pilgrimage of Mansarovara, Lachhal Kirti had already prepared the terrace of "Guru Phokto" (also called "Lachhu Jyulo") near Tatopani, a perennial source of hot water.

The sage Chandan Nath then returned to Kashmir from where he brought back paddy seed of marsi. Since the climate of Kashmir was very much similar to that of Jumla, the paddy seed brought here

${ }^{10}$ Farmers' experience of this kind has been verified form other sources as well. The officials at the Agriculture Research Centre (ARC) Jumla claimed that they had tested as more as 200 types of paddy seed (imported as well as cross-bred varieties) in Jumla. No test, however, produced any success (personal communication with Sanjaya K. Ganu, Executive Director, ARC-Jumla, June 1994).

${ }^{11}$ Personal communication with Dr. S. Ram Shah, District Agriculture Development Office, Jumla, June 1994. 
suited to the local climate very successfully. Further more the sage taught the Jyulel the techniques to be adopted and the schedule of activities to be followed in order to cultivate paddy in that harsh climate (see Table 2 for the customary calendar of paddy cultivation in Jumla). ${ }^{12}$

In Jumla, the techniques and schedule of paddy cultivation are strictly adhered to even today without alteration of any kind. The techniques and schedule have been ritualised so much that it had become a part of the Jyulel culture. The whole gamut of productive as well as festive cycles of the Jyulel culture is interwoven one with other so tightly that there is now little scope to change the system of paddy cultivation. There may be two explanations for such a strict and uniform adherence of the customary paddy cultivation in Jumla. First, it has a religious inclination. The Jyulel firmly believe that the custom was originally prescribed by the sage (now the god) Chandan Nath. This is therefore a part of their religious duty to follow it as exactly as possible.

Table 2: Customary calendar of paddy cultivation, Jumla district Date Activity

Chaitra 12 Keeping paddy seed in water to moisten.

(March, last week)

Chaitra 16 Bringing the moistened seed in the sun-light to make

(March, last week) it dry. Keeping it near hearth to maintain warmth to ease germination.

Chaitra 18-20 Sowing germinated seed in the seedbed called bennu.

(April, first week)

Jestha 1-30 Uprooting paddy seed and transplanting on the (mid-

May to mid-June) prepared land, called jyula.

Asar(mid-June to

mid-

${ }^{12}$ The supply of paddy in Jumla has also been supplemented by the distribution of paddy by Nepal Food Corporation and by the individual families concerned transporting it on their sheep.
July)

Shrawan Weeding paddy second time (once within the month).

(mid-July to mid-August)

Bhadra of

(September, the bright fortnight of the month, bring one tuft of paddy second week) at

home to offer to the god Ganesh. Flowers offered to the god

are sown back in the paddy field.

Kartik 6 onward Cutting, threshing, winnowing and harvesting of paddy. From the first harvest, one supa* of paddy, called shikh

(October, third is offered to the sage Chandan Nath. week)

Source: Field Study, Jumla, 1990 and 2013.

Note: One supa of paddy is approximately 2 kilo.

The sage Chandan Nath has been attached to the Jyulel so intimately that the legendary figure firmly predominates their perceptive as well as day-to-day activities. Second, the custom of paddy cultivation is so simple yet precise and climate-specific that the Jyulel do not have better options to substitute it. To sum up, the contribution of sage Chandan Nath to make the Khasa society of Jumla prosperous and culturally advanced is so great that the Jyulel are not in a position to avoid his influence. ${ }^{13}$ However, his influence to the Pawai is not as strong as to the Jyulel. His arrival in Jumla and his contributions in paddy cultivation and temple establishment have been very less significant to the Pawai.

Despite his overall and virtual contribution to flourish the Khasa civilization of Jumla, it was the same sage Chandan Nath who has been historically responsible for the division of the Khasa society

\footnotetext{
${ }^{13}$ Sage Chandan Nath also established a temple at the centre of Jumla Khalanga at Chhinasim. It is supposed that the temple was built at the right place where the footprints of Dattatraya, called Paduka, were found Subsequenty, the sage then established a guthi, of Dattatraya, called Paduk, were foun. Subsequently, the sage then established a guthi, land given to temple, to support the regular religious rituals and worship. The Jyulel were so obliged to the sage that the temple acquired its fame in the very have of Chandan Nath.
} 
into the Pawai and the Jyulel. The seed of paddy he introduced in Jumla was also the seed of social cleavage that resulted in the PawaiJyulel division. In course of time the gap increased so rapidly that there is a type of permanent enmity and hatredness between them. The Khasa society in pre-Chandan Nath period must have much more cohesive, organised and egalitarian. In the following section, an attempt has been made to distinguish the subsistence pattern of the Pawai to that of the Jyulel.

\section{The Pawai vs. the Jyulel livelihoods}

The entire Khasa society of Jumla can now be divided into almost two halves: the Pawai at the one end, and the Jyulel at the next (also see table 1 above). They are currently contradictory caste sub-groups and mutually exclusive pairs. Usually the mode of their relationship is characterised by exclusive "we feeling," mutual negation yet reciprocal cooperation. At the centre of their hatredness is paddy and jyula (paddy land).

Every household whether it is Pawai or Jyulel is struggling hard to have access to and control over the limited paddy land called jyula. By virtue of their settlement at the basin area, the Jyulel (those having jyula) are always the gainer at the cost of the Pawai. The later have always been marginalised in the bhuwa (dry pakho land at high elevation). Due to their differential ownership and access to jyula land there is a social cleavage between the Pawai and the Jyulel. The contrast has been reflected in their material (such as settlement, source of livelihood, dietary and dressing habits, etc.) as well as in nonmaterial culture (such as social hierarchy, power and prestige, religious and belief systems). ${ }^{14}$ Table 3 represents some of the contrasting features of the Pawai-Jyulel dichotomy.

${ }^{14}$ It is also interesting to note that the clan names of matwali Chhetri are identical too (Annex 1). Except a few, others do not match with the surnames of the non-Pawai caste groups. The non-matching of surnames is a matter of gratification and pleasure for the non-Pawai, especially for the Jyulel Chhetri, the immediately closer caste group of the local caste hierarchy. For them it is a token to disassociate their identity
Table 3: The Pawai-Jyulel ways of living

\begin{tabular}{|c|c|c|}
\hline \multirow[t]{2}{*}{ Criteria } & \multicolumn{2}{|c|}{ Livelihood characteristics } \\
\hline & The Pawai & The Jyulel \\
\hline \multirow[t]{2}{*}{$\begin{array}{l}\text { Sources of } \\
\text { livelihood }\end{array}$} & $\begin{array}{l}\text { Dry crop cultivation, } \\
\text { followed by } \\
\text { pastoralism, and } \\
\text { seasonal migration. }\end{array}$ & $\begin{array}{l}\text { Wet crop cultivation followed by } \\
\text { trade and seasonal migration. }\end{array}$ \\
\hline & $\begin{array}{l}\text { Based on lekali bhuwa } \\
\text { and sanda (all dry } \\
\text { pakho land) }\end{array}$ & $\begin{array}{l}\text { Primarily based on jyula, } \\
\text { complemented by bhuwa. }\end{array}$ \\
\hline $\begin{array}{l}\text { Jajmani } \\
\text { system }\end{array}$ & $\begin{array}{l}\text { Depend on Jyulel as } \\
\text { client }\end{array}$ & Depend on Pawai as patron. \\
\hline Settlement & $\begin{array}{l}\text { At the intermediary to } \\
\text { high elevations } \\
\text { (approx. } 2700 \mathrm{~m} \text {. to } \\
3500 \mathrm{~m} \text {.) }\end{array}$ & $\begin{array}{l}\text { Usually at the basin of rivers, } \\
\text { nearer to or in the jyula } \\
\text { (approx. } 2300 \mathrm{~m} \text {. to } 2700 \mathrm{~m} \text {.). }\end{array}$ \\
\hline $\begin{array}{l}\text { Staple } \\
\text { crops }\end{array}$ & $\begin{array}{l}\text { Barley and chino rice } \\
\text { followed by wheat, } \\
\text { buckwheat, potato and } \\
\text { millet }\end{array}$ & $\begin{array}{l}\text { Rice followed by maize, wheat, } \\
\text { potato and millet }\end{array}$ \\
\hline $\begin{array}{l}\text { Dressing } \\
\text { pattern }\end{array}$ & $\begin{array}{l}\text { Usually traditional } \\
\text { dresses such as } \\
\text { cochchhe and } \\
\text { janghelo, pauro, feta, } \\
\text { langauti* }\end{array}$ & $\begin{array}{l}\text { Usually traditional dresses such } \\
\text { as cochchhe and janghelo, pauro, } \\
\text { feta, langauti* }\end{array}$ \\
\hline & Silver ornaments. & Golden ornaments. \\
\hline \multirow[t]{2}{*}{$\begin{array}{l}\text { Social } \\
\text { hierarchy }\end{array}$} & $\begin{array}{l}\text { Matwali Chhetri (an } \\
\text { intermediate position } \\
\text { between chokha and } \\
\text { kamsel jats) }\end{array}$ & $\begin{array}{l}\text { Brahmin, Thakuri, Chhetri } \\
\text { (at the top of chokha jats). }\end{array}$ \\
\hline & $\begin{array}{l}\text { Powerless, deprived } \\
\text { and underprivileged }\end{array}$ & $\begin{array}{l}\text { Powerful (control in leadership } \\
\text { from village headman to DDC) }\end{array}$ \\
\hline $\begin{array}{l}\text { Power and } \\
\text { privilege }\end{array}$ & $\begin{array}{l}\text { Severely subordinated } \\
\text { and oppressed once } \\
\text { paddy was introduced }\end{array}$ & $\begin{array}{l}\text { Highly privileged group within } \\
\text { the feudal social structure. }\end{array}$ \\
\hline
\end{tabular}

to that of the Pawai. 
Village headman is internally powerful.

Religious The Masto and Malika and belief are the centres of their system belief system.

Festivals Localised festivals such as Pithaya

(during the Dassain), Sakranti (first day of month), Purnima (full moon), etc. are followed.

Animism Strong hold of village oracles and spirit possession (through dhami and dangri)

Source: Field Study, Jumla, 1990.

Note: They are long fitting dresses called labeda followed by Nepali trousers,

waist band, head-cloth, lion-cloth made up of hand-loomed thetuwa (cotton) and feruwa (woolen), respectively.

It is important to reiterate that the Jyulel economy is primarily based on and shaped by the paddy culture. Their access to jyula land has been reflected in their ritual, economic, social and even the rhythm of their movement so strongly that the whole gamut of their living has been ritualised in and around paddy. For example, all of the Jyulel migrants are expected to come back to their homes by $12^{\text {th }}$ of Chaitra each year. It is customarily necessary that they participate in rice plantation process right from the beginning. The 12th of Chaitra is the exact day paddy seed is kept in water to moisten it. In the past, the custom was so strong that the family members used to perform funeral rites for the ones who did not arrive home by that date supposing that she/he must have died.

This custom, however, has been laxed so far as the Pawai are concerned, who too happened to stay within the common niche. Since the Pawai are devoid of jyula land, they basically derive their livelihood by rearing livestock and practicing pakho-based agriculture. As a supplement to their economy they also practice transhumance. Sheep are taken to Jajarkot in the month of Mangsir (November-December) and kept there for three months. In their way back to home from Chaitra (March-April) onward, they carry loads (such as rice, bought or bartered). ${ }^{15}$

During the subsequent two months the sheep are kept at home. In the month of Asadh (June), sheep are taken to high altitude pastures, called patan, kept upto Ashwin (October). Those who do not take their sheep to Jajarkot move to patan for summer grazing. Grazing patterns vary within and between ecological belts spatially, temporally and also according to the animals involved. In the low altitude basin (i.e., for the Jyulel), the pattern of grazing movement is a simple transhumance. In the higher elevation (i.e., for the Pawai) more extensive movement of animals is necessary (Bishop, 1990).

Despite some of these differences including the sense of rooted hatredness and cleavage, both the Pawai and the Jyulel are the part of the same system of human ecology. The nature-culture interface, found in Jumla, is similar to both of these groups. It also necessitated them to maintain a kind of inter-group relationship and mutual inter-dependence. The bond of relationship between the Pawai and Jyulel has been described as follows:

There is [an] inseparable linkage between Pawai and Jyuleli because of complimentarity of their economies. Generally the exchange between Pawai and Jyuleli takes place in the form of barter. Pawai barter peas, cereals, garlic, honey, wheat and barley, animals and animal products for rice. Pawai also provide labor to carry rice. Pawai generally are short of oxen driven ploughs and needs [sic] them when Jyuleli do not. Pawai borrow oxen to plough in the month of Srawan (July-August) when oxen are more of a burden to Jyuleli and return in Kartik (October-November) just in time for preparation of

${ }^{15}$ Usually such loads are kept in a pair of lukals (sacks made of goat-skin) suspended from the back of goats or sheep. 
the field for wheat plantation[.] [I]n turn Pawai help to carry paddy (Manandhar et al., 1993:36).

\section{Some concluding statements}

Both the Pawai and the Jyulel are the Khasa by their native association of origin. Originally, it is assumed that, the Khasa society did not have social stratification such as caste. By and large, it was an egalitarian society because of its inhabitation in the remote, inaccessible and very marginal geography of the Himalayan range. Due to their simple way of living based on subsistent economy comprised of high altitude farming, terracing, slash-and-burn cultivation largely supplemented by trade and transhumance we can very safely infer that their economy was not much heterogeneous. However, because of their strong social organisation based on agrarian social structure (such as feudalism) of the Karnali basin, once the Khasa were successful to establish a regionally powerful Khasa empire. The Khasa Kingdom at that time was culturally and politically unique and appealing. It served also as a gateway for the diminishing trans-Himalayan trade. The existence of the sacred complex of Mansarovara and Kailash behind its domain in the north too helped extend its repute.

This is in this context that one of the famous religious saints of Kashmir called the sage Chandan Nath arrived here in Jumla on his way to Mansarovara. It is Chandan Nath who contrived to make the Valley of Jumla inhabitable, introduced paddy cultivation there, and established famous temple of Datatreya (now called the temple of Chandan Nath) in Jumla Khalanga. His contributions such as these were so vital to the Khasa society that the Khasa civilization was really sparkled then onward.

The introduction of paddy including techniques and schedules of its plantation even in that harsh climatic zone was so successful that the social economy of the Khasa boomed in its full extent. The contributions of the sage Chandan Nath were, however, not always positive. It served mainly the Khasa inhabiting in or around of the basins of Tila, Sinja, Bheri and Choudhabisa rivers who already had control over the fertile basin land. Introduction of paddy cultivation had nothing to do for the highland dwellers such as the Pawai whose subsistence was based on dry crop cultivation.

Due to the innovation of paddy cultivation a very clear and considerable gap appeared in the social economy of Khasa society. Those who were fortunate to receive its benefits (by virtue of their command over jyula land) evolved as powerful and privileged section of the society. Their descendants are the present day Jyulel. Likewise, the ones deprived of any benefits of this kind were marginalised not only in economy but also in power and privilege. Their descendants are the present day Pawai.

To sum up, based on the discussions made above we can infer some simple yet basic conclusions. My first argument is that since the introduction of paddy is relatively a recent incident in Jumla, the paddy-based social dichotomy of the Pawai and the Jyulel too is a recent development. I would like to reiterate once again that social efficiency of the Jyulel of obtaining paddy has been instrumental to make them socio-economically forward vis-a-vis the Pawai who too were a part of the same niche. Second, which is a corollary of the first, the special designation of matwali Chhetri to the Pawai was not defilement for their defiance against Brahminisation as is claimed by Bista (1996) and Bishop (1990). It was just an adjective coined by the Jyulel as a part of their effort of obtaining "lofty rank and the honours of the Kshatriya order" by making as much detachment as possible with the Pawai. In the sense, this was absolutely an intra-Khasa affair. The so-called "Brahminisation" as such is just an accusation on the part of academicians for their inability of analysing social dynamics in sufficient detail. Third, ethnographically, the Pawai are now very distinct to that of Chhetri, Thakuri and even the Khasa of the West Nepal. It is now high time to recognise their independent identity demographically as well as ethnographically. I, therefore, suggest not merging them under Chhetri caste group being insensitive to them during ethnographic and other types of social analysis of Jumli Khasa society. 


\section{References}

Bishop, B. (1990) Karnali under Stress: Livelihood Strategies and Seasonal Rhythms in Changing Nepal Himalaya, Chicago: University of Chicago Press.

Bista, Dor B. (1996) People of Nepal, sixth edition, Kathmandu: Ratna Pustak Bhandar.

Ghurye, G. S. (1961) Caste, Class and Occupation, Bombay: Popular Book Department.

Gurung, H. (1980) Vignettes of Nepal, Lalitpur: Sajha Prakashan.

Luintel, Y. R. (1993) "The Pawai," an ethnographic entry for the Cultural Encyclopaedia of Nepal, Kathmandu: The Cultural Encyclopaedia of Nepal Project, The Toyota Foundation.

Manandhar, M.S., N. R. Karmacharya, Y. R. Luintel and N. B. Raut (1993) "Development strategies of the remote areas of Nepal: The case of Jumla district," a report submitted to IDRC Canada by the Centre for Nepal and Asian Studies.

NESAC (1998) Nepal Human Development Report 1998, Kathmandu: Nepal South Asia Centre.

Sharma, P. R. (1971) "The Matawali Chhetris of Western Nepal," The Himalayan Review, vol. IV, pp. 43-60.

Shrestha, B. K. (1993) A Himalayan Enclave in Transition: A Study of Change in the Western Mountains of Nepal, Kathmandu: Integrated Centre for Mountain Development.

Shrestha, B. K. (2028 BS) Diyar Gaon ka Thakuri Haru, Kathmandu: Royal Nepal Academy (text in Nepali).

Srinivas, M.N. (1969) "The caste system in India" in Andre Betleille ed. Social Inequality, New Delhi: Penguin Books.

Tucci, G. (1962) Nepal: The Discovery of the Malla, London: Allen and Unwin.

UNDP (2006) Nepal Human Development Report 2006, Kathmandu: United Nations Development Programme Nepal.

UNDP (2009) Nepal Human Development Report 2006, Kathmandu: United Nations Development Programme Nepal.

\begin{tabular}{|c|c|}
\hline $\begin{array}{l}\text { Ethnic/Caste } \\
\text { groups } \\
\text { (on } \\
\text { alphabetic } \\
\text { order) }\end{array}$ & Clan names \\
\hline "Bhote" & Aindi, Budha, Dorje, Lama, Mahatara, Rokaya, Tamang \\
\hline Brahmin & $\begin{array}{l}\text { Acharya, Adhikari, Bhatta, Bhattarai, Choulagain, Devkota, } \\
\text { Dhakal, Dhital, Gautam, Gotame, Kafle, Khanal, Neupane, } \\
\text { Padhya, Pandit, Parajuli, Poudyal, Pyakude, Pyakurel, } \\
\text { Regmi, Rupakheti, Sanjyal, Simkhada, Tiwari, Upadhya, } \\
\text { Upadhyaya }\end{array}$ \\
\hline Chhetri & $\begin{array}{l}\text { Adhikari, Badhuwal, Baniya, Basnet, Bhandari, Bharma, } \\
\text { Bhawari, Bista, Bogati, Bohora, Budha, Budhathoki, } \\
\text { Budthapa, Dangri, Gharti, Jaisi, K.C., Kahar-Budha, } \\
\text { Karki, Kathayat, Khadka, Khadka, Khand, Khatri, Kumai, } \\
\text { Mahat, Mahatara, Nagarkoti, Nepal, Pande, Rana, Rawat, } \\
\text { Roka, Rokaya, Sainjuwal, Samal, Seruwal, Simkhada, Swar, } \\
\text { Thami, Thapa }\end{array}$ \\
\hline Damai & Dholi, Nepal \\
\hline Kami & $\begin{array}{l}\text { Badkami, Bherikar, Bishwakarma, Bitalu, Kami, Kandara, } \\
\text { Luwar, Maharjan, Mijar, Nepal, Nepali, Odkami, } \\
\text { Subarnakar, } \\
\text { Sunar, Tiruwa }\end{array}$ \\
\hline Kamsel & Chanara, Dharala, Kalal, Kewar \\
\hline Magar & Dhenga-Magar, Puna, Thapa-Magar \\
\hline $\begin{array}{l}\text { Matwali } \\
\text { Chhetri }\end{array}$ & $\begin{array}{l}\text { Aindi, Baduwal, Banikote, Bhakri, Bhavari, Ghatru, Gharala, } \\
\text { Hasulli, Hitan, Mahari, Mahatara, Pachhain, Rawat, Reunle, } \\
\text { Sainjuwal, Saud, Thakulla, Thami, Thyaeet }\end{array}$ \\
\hline Sanyasi & Bharati, Giri, Puri, Yogi \\
\hline Sarki & Nepali, Luwa \\
\hline Thakali & Bhattachan, Serchan, Thakali \\
\hline
\end{tabular}

Source: Field study, Jumla, 1990 and 2013.

Note: This is not an exhaustive list of clan names in Jumla, but it is just an indicative one. 